\title{
Developing natural gas vehicle market as a basis for industrialized future of territorial sustainability
}

\author{
Elena Kulikova*, Olga Durandina, and Elena Molokova \\ Ural State University of Economics, Yekaterinburg, Russia
}

\begin{abstract}
This study is devoted to one of the factors of sustainable development of the territory - the regional transport system. One of the most important elements that determine the competitiveness of the system is the market for natural gas fuel. In the Russian Federation, there are state support programs with a scenario of advanced development, as it directly affects the regional economy and, accordingly, provides the basis for sustainable development and the quality of life. The article describes the state and prospects of road transport development in the Ural region related to the transition to natural gas. The advantages of natural gas from the perspective of motor fuel in the context of the economic component of regional development are evaluated. The measures necessary to create conditions for the development of gas-engine infrastructure for the mass use of natural gas vehicles are determined.
\end{abstract}

\section{Introduction}

One of the main factors of sustainable development and increasing the regional competitiveness is road transport. It acts as a kind of economic driver which affects the efficiency of the regional economic system.

In order to develop road transport, it is necessary to use effective innovative technologies and create a developed infrastructure that builds a competitive level compared to foreign analogues.

In the Russian Federation, there are programs of state support for the transition of public road transport to gas fuel [1]. The main advantages of using liquefied natural gas as a motor fuel are:

- possibility to deliver the product (CNG and $\mathrm{LNG})$ to the locations of gas engine fuel consumers;

- $\quad$ independence of gas filling stations from the presence of a gas supply pipeline;

- possibility of increasing the capacity of the gas station in relation to the increase in demand.

Currently, the introduction of natural gas vehicles and equipment in the subjects of the Russian Federation is carried out within the framework of the Transport Strategy of the

\footnotetext{
${ }^{*}$ Corresponding author: e.s.kulikova@mail.ru
} 
Russian Federation within the period up to 2030 [2]. In March 2020 a decree of the Government of the Russian Federation amended the state program of the Russian Federation "Energy Development". The document is also supplemented by the sub-program "Development of the gas engine fuel market" [3]. The goal of the subprogram is to increase the consumption of natural gas as a motor fuel, to develop gas filling infrastructure, to increase the fleet of natural gas vehicles [3].

The concept of the subprogram "Development of the gas engine fuel market" contains a scenario of advanced development with planned indicators of 2024: an increased consumption of natural gas as motor fuel to 2.7 billion $\mathrm{m} 3$; the number of stationary gas filling facilities should be at least 1273 units; an increase of at least 40 thousand units in the number of natural gas vehicles.

\section{Material and methods}

Implementing the subprogram in the period from January 1, 2020 to December 31, 2024 it is planned to allocate 19.29 billion roubles from the federal budget to develop the gas engine fuel market (GMF). 27 Russian regions participate: these are the regions that have a basic gas filling infrastructure and are located along the country's key federal highways. The adopted concept will make it possible to form gas-engine corridors and create a complete gas-filling infrastructure in the European part of Russia. In large cities, the government of the Russian Federation has defined the main task - to transfer public road transport to natural gas.

As far as the history of the formation of the domestic gas engine fuel market is concerned, we consider 2013 to be decisive for the development: the government decision transferred at least $50 \%$ of public road transport to gas fuel.

In the Sverdlovsk region the requirements of the resolution affected Yekaterinburg, Chelyabinsk and five other industrial cities. Since this period, an active process of transferring transport to methane has begun in many regions of Russia. Cooperation agreements were signed with twenty-six Russian regions in 2013-2014. The total amount of funding the program for the period 2015-2020 amounted to 109 billion 736 million 901.2 thousand roubles. Technical, technological and regulatory features of using natural gas have exacerbated the problem of creating the necessary refueling infrastructure.

Noting the positive effect of applying natural gas to transport with the impact on the environment [4], it is necessary to take into account a very important economic component. Thus, the low cost of natural gas and government subsidies make the gas-powered equipment economically beneficial. Production costs (goods, services), purchasing motor fuel can reach more than 30 percent, so the use of a cheaper alternative type of motor fuel is of important socio-economic importance for enterprises and organizations (the cost of 1 cubic meter of $\mathrm{CNG}$ consumption in the region is 3.6 times lower than the cost of 1 liter of diesel fuel) [5].

The development of the infrastructure of the transport complex in the Sverdlovsk region is related to the implementation of the government program to increase the use of natural gas as motor fuel in public road transport and transport of road and municipal services.

According to the Department of the State Road Safety Inspectorate of the Ministry of Internal Affairs of the Russian Federation for the Sverdlovsk Region, as of 01.12.2020, 1 622.5 thousand vehicles are registered in the Sverdlovsk region: 21.8 thousand buses $(1.3$ $\%) ; 199.5$ thousand trucks $(12.3 \%) ; 1401.3$ thousand passenger cars $(86.3 \%)$. Taking into account the annual increase in the number of vehicles by $4 \%$ on average, there is an urgent need to provide it with high-quality motor fuel with improved environmental characteristics. 
The Sverdlovsk region has contributed to the development in this direction, purchasing eco-friendly buses, but at the moment the established standard of $50 \%$ is not reached. In Yekaterinburg, there are not enough gas-powered buses. In Yekaterinburg, there are about 2 thousand units of municipal transport, 169 buses run on gas. The city serves about 1 thousand buses and minibuses. In relation to the total number of vehicles, in Yekaterinburg from $8.45 \%$ to $16.9 \%$ of municipal buses and minibuses are converted to gas-powered fuel. From 2015 to 2017, the Yekaterinburg City Board purchased 169 low-floor gas-powered buses from the Minsk and Neftekamsk Automobile Plants making arrangements for the World Cup. For the first batch, the budget paid 703 million rubles, for the second -710 million rubles, for the purchase of the third batch of transport, the city administration signed a leasing contract with Gazprombank Leasing JSC for 888 million roubles.

According to the Russian Transport Strategy by 2030, the share of the fleet with engines on alternative fuels (gas-engine fuel) should be at least $49 \%$. However, the process of converting road transport to gas-powered fuel is very slow, NGV- no more than $5 \%$ of the total fleet.

\section{Results and discussions}

The main reason of low demand for gas vehicles is the poorly developed infrastructure of the industry: the limited number of automobile gas-filling compressor stations (CNG stations) in the region. The situation of natural gas vehicles resembles a vicious circle. It is assumed that gas filling stations should be available everywhere. However, today in the Sverdlovsk region there is no network of such filling stations, therefore, there is no need for gas engine vehicles.

In the Ural region, the main segment of the gas engine market (Sverdlovsk, Chelyabinsk, Orenburg and Kurgan regions) is successfully developed by Gazprom Transgaz Yekaterinburg. The organization specializes in using natural gas on public transport and the introduction of advanced production technologies. For example, the complete technological chain of LNG circulation, production, transportation and use, was implemented by Gazprom Transgaz Yekaterinburg LLC in Moscow in Pervouralsk, at the first automobile gas-filling compressor station $(\mathrm{CNG})$ in the region.

In 2016, the Gazprom Management Board adopted a Program for developing lowtonnage Production and Use of Liquefied Natural Gas (LNG) which formulated a list of promising gas distribution stations (GDS) and liquefaction technologies [6].

The main activities of Gazprom Transgaz Yekaterinburg LLC are the sale of natural gas as motor fuel, the operation of a network of automobile gas-filling compressor stations (CNG stations), transition of motor vehicles to run on gas-engine fuel. Over the past decade, the company has opened thirty-one CNG stations. In Yekaterinburg, Magnitogorsk, Chelyabinsk, Krasnogorsk and Shadrinsk, there are six car conversion points. At present the main consumers of gas engine fuel in the Ural region are urban passenger vehiclesminibuses such as buses "PAZ" and $\mathrm{m} /$ buses "Gazelle".

Simultaneously with implementing the integrated program of the Sverdlovsk region for the period 2014-2020 within the framework of the corporate program, the company successfully implements its Comprehensive Target Program for the period up to 2023 on the use of natural gas as a motor fuel for departmental transport.

The main goals of the Program are:

- reducing the cost of freight transport work by increasing the profitability of the production and sale of natural gas fuel;

- increase in the volume of natural gas sales in the domestic market of the Russian Federation at world prices; 
- reduction of harmful emissions into the atmosphere through the use of cleaner fuels: liquefied natural gas (LNG) and compressed natural gas (CNG);

- $\quad$ ensuring the efficiency of production and sales of compressed natural gas (CNG) at automobile gas-filling compressor stations, through the production of liquefied natural gas (LNG) at low-load CNG stations involved in the Comprehensive Target Program;

- $\quad$ sale of compressed natural gas $(\mathrm{CNG})$ regasified from $\mathrm{LNG}$ at cryogenic gas filling stations (CryoGNS) built within a radius of $50 \mathrm{~km}$ from them;

- developing the network of automobile gas-filling compressor stations (CNG stations) through the construction of new CNG stations and cryogenics;

- $\quad$ providing 600 departmental gas-cylinder cars with gas-engine fuel.

The main objective of the Program was to diversify the ways of gas supply to consumers and to provide Gazprom Transgaz Yekaterinburg LLC's departmental vehicles with gas-engine fuel in the required volumes.

The period of implementing the Program period is 2013-2023. The financing is carried out at the expense of the company's funds. During the implementation of the program measures, the "Target comprehensive program for the development of the gas filling network and the fleet of natural gas-powered vehicles for 2007-2015" was completed, approved by Order No. 71 of LLC Gazprom dated 20.03.2007, on the conversion of automatic telephone exchanges to $\mathrm{CNG}$ and ensuring their refueling with the use of gas filling stations. The main characteristics of the existing CNG CP are given in Table 1.

Table 1. Main characteristics of the $\mathrm{CP}$ of liquefied natural gas (LNG).

\begin{tabular}{|l|c|c|c|c|}
\hline \multicolumn{1}{|c|}{$\begin{array}{c}\text { LNG production } \\
\text { Complex }\end{array}$} & $\begin{array}{c}\text { LNG storage } \\
\text { capacity }\end{array}$ & $\begin{array}{c}\text { Design } \\
\text { capacity, } \\
\text { t/ } h\end{array}$ & $\begin{array}{c}\text { Type of natural gas } \\
\text { liquefaction plant }\end{array}$ & $\begin{array}{c}\text { Year of setting for } \\
\text { pilot operation }\end{array}$ \\
\hline $\begin{array}{l}\text { CNG CP at CNG } \\
\text { stations in Pervouralsk }\end{array}$ & $44 \mathrm{~m} 3$ & 0,8 & 082 & 2005 \\
\hline $\begin{array}{l}\text { CP LNG at GRS-4 } \\
\text { Sverdlovsk }\end{array}$ & $200 \mathrm{~m} 3$ & 3,0 & OPG-3-3-0,6 & 2011 \\
\hline
\end{tabular}

Currently, four Ural regions which are an area of operation of Gazprom Transgaz Yekaterinburg have 30 automobile gas filling compressor stations (CNG stations), 2 CNG stations and 6 mobile gas filling stations (MGFZ) that refuel cars and other compressed natural gas vehicles. The main characteristics of CNG filling stations are given in Table 2.

Table 2. Main characteristics of automobile gas-filling compressor stations (CNG stations).

\begin{tabular}{|c|c|c|c|c|c|}
\hline CNG station & $\begin{array}{l}\text { Type of CNG } \\
\text { filling station }\end{array}$ & 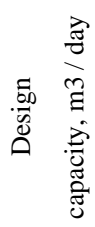 & 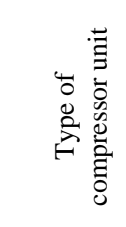 & 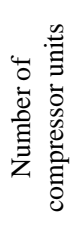 & 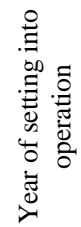 \\
\hline Ekaterinburg № 2 & ACSGF -500 & 35000 & 2GM4 & 5 & 1984 \\
\hline Chelyabinsk № 1 & ACSGF - 500 & 35000 & 2GM4 & 5 & 1984 \\
\hline Ekaterinburg № 1 & ACSGF -500 & 35000 & 2GM4 & 5 & 1985 \\
\hline Chelyabinsk № 2 & ACSGF -500 & 35000 & 2GM4 & 5 & 1985 \\
\hline Magnitogorsk № 1 & ACSGF -500 & 35000 & 2GM4 & 5 & 1985 \\
\hline Magnitogorsk № 2 & ACSGF - 500 & 35000 & $2 \Gamma \mathrm{M} 4$ & 5 & 1985 \\
\hline Nizhny Taghil № 2 & ACSGF -500 & 35000 & 2GM4 & 5 & 1985 \\
\hline Neviansk & ACSGF -500 & 35000 & $2 \mathrm{GM} 4$ & 5 & 1985 \\
\hline Pervouralsk & ACSGF -500 & 35000 & 2GM4 & 5 & 1985 \\
\hline Zlatoust & ACSGF - 500 & 35000 & 2GM4 & 5 & 1985 \\
\hline Ekaterinburg № 3 & ACSGF - 500 & 35000 & $4 \mathrm{NR} 3 \mathrm{KN}$ & 2 & 1986 \\
\hline Orsk & ACSGF -500 & 35000 & $4 \mathrm{NR} 3 \mathrm{KN}$ & 2 & 1986 \\
\hline
\end{tabular}


Table 2. Continued

\begin{tabular}{|c|c|c|c|c|c|}
\hline Kamensk-Uralsky & ACSGF - 500 & 35000 & 4NR3KN & 2 & 1987 \\
\hline Nizhny Taghil № 1 & ACSGF - 500 & 35000 & 4NR3KN & 2 & 1987 \\
\hline Chelyabinsk № 3 & ACSGF -500 & 35000 & 2GM4 & 5 & 1987 \\
\hline Polevskoy & BKI-250 & 17500 & 4GM2,5 & 3 & 1988 \\
\hline Orenburg № 3 & ACSGF - 500 & 35000 & 4NR3KN & 2 & 1988 \\
\hline Kurgan & MBKI- 250 & 17500 & 4GM2,5 & 3 & 1989 \\
\hline Mednogorsk & BKI -250 & 17500 & $2 \mathrm{HB} 2 \mathrm{~K}$ & 3 & 1990 \\
\hline Ilek № 7 & MBKI - 250 & 17500 & 4GM2,5 & 3 & 1990 \\
\hline Shadrinsk & MBKI - 250 & 17500 & 4GM2,5 & 3 & 1995 \\
\hline Kartaly & BKM - 100 & 7000 & $2 \mathrm{HB} 2 \mathrm{~K}$ & 1 & 1996 \\
\hline Krasnogorsk & $\mathrm{BI}-40$ & 2800 & B 30-30 & 1 & 2001 \\
\hline Dolgoderevenskoye & $\mathrm{BI}-40$ & 2800 & ST 75 & 1 & 2002 \\
\hline Peschano-Koledino & $\mathrm{BI}-40$ & 2800 & $6 \mathrm{GSH}$ & 1 & 2004 \\
\hline Orenburg & $\mathrm{BI}-40$ & 2800 & $6 \mathrm{GSH}$ & 1 & 2006 \\
\hline Sysert & $\mathrm{BI}-70$ & 4900 & B 30-30 & 1 & 2006 \\
\hline Goluboy Fakel & $\mathrm{BI}-70$ & 4900 & B 30-30 & 1 & 2006 \\
\hline Nizhny Taghil № 3 & BI -250 & 17500 & SW 132 & 2 & 2006 \\
\hline $\begin{array}{l}\text { Nizhny Taghil № } 4 \\
\text { (MTAZS) }\end{array}$ & $\mathrm{BI}-150$ & 10500 & BS 302 & 1 & 2009 \\
\hline
\end{tabular}

The annual design capacity of CNG stations is 250.4 million $\mathrm{m} 3$ of compressed natural gas (CNG). In 201956.5 million $\mathrm{m} 3$ of CNG was produced, 53.5 million m3 was sold to third-party vehicles and 3 million $\mathrm{m} 3$ was released to departmental vehicles. In areas lacking in stationary $\mathrm{CNG}$ stations the company widely uses mobile automobile gas tankers (MAGT) designed for filling vehicles with compressed natural gas (CNG).

Schedule of operating mobile automobile gas tankers (MAGT) is presented in Table 3.

Table 3. Locating mobile automobile gas tankers (MAGT).

\begin{tabular}{|c|c|c|c|c|}
\hline Subsidiary & Type & Reg. № & State & $\begin{array}{c}\text { Term of the next } \\
\text { technical } \\
\text { inspection of the cylinders }\end{array}$ \\
\hline $\begin{array}{c}\text { Shadrinsk LPO } \\
\text { (GCS Shatrovsky) }\end{array}$ & MGFS KZAP & AE 9502** & in working order & $\begin{array}{c}\text { January 2017 } \\
\text { (without ABS) }\end{array}$ \\
\hline $\begin{array}{c}\text { Mednogorskoe } \\
\text { LPO } \\
\text { (GCS Saraktash) }\end{array}$ & MGFS KZAP & AH 5602 & $\begin{array}{c}\text { in working order } \\
\text { (in operation) }\end{array}$ & $\begin{array}{c}\text { August 2017 } \\
\text { (without ABS) }\end{array}$ \\
\hline DUSV (Aramil) & MGFS KZAP & AC 9050** & in working order & $\begin{array}{c}\text { June 2013 } \\
\text { (ABS inst. 07.2012) } \\
\text { May 2014 } \\
\text { (ABS inst. 06.2012) }\end{array}$ \\
\hline DUSV (Shadrinsk) & MGFS KZAP & AK 5004* & in working order & $\begin{array}{c}\text { August 2014 года } \\
\text { (ABS inst. 05.2012) }\end{array}$ \\
\hline DUSV (Shadrinsk) & MFGS DK & T 177 TX** & in working order & September 2019 \\
\hline
\end{tabular}

* - MGFZis used to supply CNG to the GBA at the Shatrovo gas station (p. Kyzylbay);

** - MGFZ is used for refueling the gas turbine at the Kurgan CNG station;

*** - Gas pumps are used from May to October to supply gas to consumers during repair work on gas pipelines-branches.

However, the company's facilities for the production and sale of compressed natural gas (CNG) cannot fully meet the needs of departmental natural gas vehicles in the area of responsibility where the unified gas transportation system is serviced. Taking into account the planned increase in the fleet by 600 units of natural gas vehicles it is necessary to construct $\mathrm{CNG}$ stations at the sites of subsidiaries and in places that exclude the idle run of the gas turbine engine at the GMF in the area of operation of the enterprise, and to purchase a gas-fueled gas station for vehicles operating away from the $\mathrm{CNG}$ stations. The required amount of CNG to provide 600 units of HBA is 12 million $\mathrm{m} 3$ per year. 
Target Comprehensive Development Program 2017 resulted in the increased fleet of departmental $\mathrm{CNG}$ vehicles to 934 units through replacing existing diesel and gasoline vehicles with the same type of methane cars up to 615 units.

Diesel engine vehicles running on the gas-diesel cycle were replaced with natural gas vehicles, the sales of CNG for the currently available 107 units of diesel cars in the branches of Gazprom Transgaz Yekaterinburg LLC increased from the reported 547,580 $\mathrm{m} 3$ / year to $1,095,160 \mathrm{~m} 3 /$ year, and additional savings due to the use of CNG instead of liquid engine fuel amounted to 7,119 million roubles / year.

The schedule for increasing the departmental fleet of equipment operating at the GMF is presented in Table 4.

Table 4. Schedule for increasing the departmental fleet of gas-powered vehicles.

\begin{tabular}{|c|c|c|c|c|c|c|c|c|}
\hline \multirow{3}{*}{ Subsidiary } & \multicolumn{8}{|c|}{ Quantity of NGV } \\
\hline & \multicolumn{8}{|c|}{ Year } \\
\hline & 2013 & 2014 & 2015 & 2016 & 2017 & 2018 & 2019 & 2020 \\
\hline Alekseevskoe LPO & - & - & - & - & - & 9 & 17 & 26 \\
\hline Buzulukskoe LPO & - & - & - & - & - & 9 & 17 & 25 \\
\hline Dalmatovskoe LPO & 28 & 32 & 36 & 40 & 41 & 41 & 41 & 41 \\
\hline Dombarovskoe LPO (c KC-16) & 33 & 37 & 41 & 46 & 48 & 48 & 51 & 52 \\
\hline Kartalinskoe LPO & 26 & 29 & 33 & 36 & 39 & 41 & 44 & 44 \\
\hline Krasnogorsk LPO & 45 & 47 & 52 & 54 & 54 & 54 & 54 & 54 \\
\hline Magnitogorsk LPO & 20 & 23 & 25 & 25 & 29 & 31 & 34 & 34 \\
\hline Maloistokskoe LPO & 38 & 43 & 45 & 48 & 52 & 53 & 55 & 55 \\
\hline $\begin{array}{l}\text { Mednogorskoe LPO } \\
\text { (with Saraktash GCS) }\end{array}$ & 32 & 35 & 35 & 37 & 41 & 49 & 51 & 51 \\
\hline Nevyansk LPO & 16 & 22 & 23 & 27 & 27 & 31 & 34 & 36 \\
\hline Orenburg LPO & 15 & 17 & 19 & 24 & 27 & 29 & 29 & 29 \\
\hline Chelyabinsk LPO & 34 & 36 & 39 & 43 & 43 & 43 & 47 & 49 \\
\hline $\begin{array}{l}\text { Shadrinsk LPO } \\
\text { (with Shatrovsky GCS) }\end{array}$ & 31 & 34 & 37 & 41 & 45 & 52 & 52 & 54 \\
\hline ATS- 1 & 14 & 17 & 19 & 23 & 27 & 33 & 37 & 41 \\
\hline ATS -2 & 23 & 26 & 29 & 35 & 39 & 43 & 48 & 49 \\
\hline ATS - 3 & 36 & 41 & 42 & 46 & 46 & 49 & 54 & 54 \\
\hline ATS - 4 & 13 & 17 & 22 & 26 & 29 & 34 & 36 & 36 \\
\hline ETC & 14 & 14 & 17 & 18 & 22 & 24 & 24 & 24 \\
\hline SUEZC & 8 & 9 & 11 & 13 & 16 & 19 & 19 & 22 \\
\hline Network management & 4 & 5 & 5 & 5 & 5 & 5 & 5 & 5 \\
\hline DUSV & 77 & 84 & 96 & 105 & 117 & 135 & 146 & 153 \\
\hline Total & & & & & & & & 934 \\
\hline
\end{tabular}

Along with the transition of departmental transport to gas-powered fuel, nine facilities for the production and sale of gas-powered fuel (CNG stations and Cryo STS) and one facility for the conversion and maintenance of natural gas-powered vehicles (PPA and TOB) are being built as part of the Comprehensive Target Program. The need for capital investments in the construction of nine $\mathrm{CNG}$ stations and re-equipment and maintenance of natural gas vehicles (PPA and TOB) amounted to 426,300 thousand roubles, that also involved:

- construction of the Aramil CNG station (CNG from LNG) 87,320 thousand RUB,

- construction of CNG filling stations GKS Saraktash 30680 thousand RUB 
- $\quad$ construction of the CNG G. Plast 80240 thousand RUB

- construction of CNG filling stations GKS Shatrovo 30680 thousand RUB

- $\quad$ construction of CNG filling stations Buzuluk 59000 RUB

- construction of CNG filling stations Mednogorsky LPU 30680 thousand RUB

- construction of CNG filling stations GCS of Burdygina 30680 thousand RUB

- $\quad$ construction of the CNG S.Manchazh 39,260 thousand RUB

- construction of the Alekseevskoe LPU CNG station 23,600 thousand RUB,

- $\quad$ construction of the PPA and TOB 14,160 thousand RUB.

The discounted pay-off period of the construction program was 9.5 years.

During the period from 2001 to the present day Gazprom Transgaz Yekaterinburg LLC developed gas filling infrastructure facilities in different ways: cryogenic LNG and CNG gas filling stations (CryoAZS), gas filling facilities of block-modular design (CNG module from LNG), cryogenic mobile automobile gas tankers (CryoPAGZ). Since January 2017 the Ural Gas Transportation Company has been supplying its own LNG to the Republic of Kazakhstan for autonomous gasification and refueling of motor vehicles with gas-powered fuel. At the end of 2020 the total volume of these deliveries exceeded 280 tons [7].

\section{Conclusions}

The implemented comprehensive target program made it possible to draw the following conclusions:

- the development and widespread introduction of technologies for the production of liquefied natural gas (LNG) opens up great opportunities for a new segment of the gas engine fuel market in the Ural region.

- Gazprom Transgaz Ekaterinburg is the leading operator of the technological scheme for the low-tonnage production, transportation and use of liquefied natural gas.

- the formation and development of the gas engine fuel market is a strategic task that determines the industrial future of the territory (Sverdlovsk, Kurgan, Chelyabinsk, Orenburg regions);

- the program method for developing the gas engine fuel market in the Ural region has a positive impact on both the internal environment and external environment of the enterprise as the construction of new CNG stations attracts a larger number of enterprises using gas engine fuel increasing the profitability of production;

- $\quad$ city buses, road-utility vehicles, light commercial vehicles, and taxis are planned to continue to run on $\mathrm{CNG}$ as an alternative to traditional liquid motor fuel.

At the same time, researchers have mentioned [7-10], there are barriers in Russia that prevent the widespread introduction of LNG as a motor fuel, in particular:

- there is no developed production and supply infrastructure for liquefied natural gas (LNG) as a motor fuel;

- $\quad$ the center for coordination of strategic efforts has not been formed;

- $\quad$ flawed legal and regulatory framework;

- $\quad$ high cost of foreign technological equipment, LNG vehicles;

- no in-house mass production of gas-powered vehicles.

The lack of preparation of the infrastructure for the mass use of natural gas vehicles is the main obstacle to implementing in this direction. In turn, the development of gas-engine infrastructure hinders the coordinated processes of creating a gas filling network and increasing the fleet of gas-engine transport. This problem can be solved through a comprehensive approach which involves systematic measures aimed at accelerating the transition to gas-engine fuel, creating a modern infrastructure for this market through 
constructing new and modernization of facilities, automobile gas-filling compressor stations, multi-fuel filling stations and service points for gas-cylinder equipment.

The use of natural gas as a natural gas engine fuel provides significant social and economic benefits and reduces environmental costs. Having huge natural gas reserves, highest level of production in the world, and a developed system of main and distribution gas pipelines, Russia is expected to operate effectively in this market. Improving energy and environmental security of the territory, increasing the competitiveness of the regional economy are the major factors. The sale of liquefied natural gas in the motor fuel market provides a leading position through the diversified products and increased sales in the domestic Russian market.

\section{References}

1. Translation of transport to gas fuel, https://rg.ru/

2. Transport strategy of the Russian Federation for the period up to 2030

3. Decree of the Government of the Russian Federation of March 2, 2020 No. 221 "On Amendments to the State Program of the Russian Federation"Development of Energy "

4. The negative impact of transport on the environment, https://vtorothodi.ru/

5. I.V. Makarova, R.G. Khabibullin, L.M. Habsalikhova, I.I. Valiev, Basic Research, 10(6), 1209 (2013)

6. Prospects and risks of transfer of automotive transport to gas engine fuel, http://fundamental-research.ru/

7. Resolution of the PJSC Gazprom Management Committee dated October 26, 2016 "On Approval of the Program for the Development of Low-Tonnage Production and Utilization of Liquefied Natural Gas"

8. A.V. Kryukov, Gas industry, S1(766), 30 (2018)

9. Sh.A. Smagulova, A.D. Omarov, A. Zh. Zhanuzak, Strategic and Project Management, 8, 247 (2016)

10. S. Pfoser, G. Aschauer, L. Simmer, O. Schauer, Research in Transportation Business \& Management, 18, 77 (2016)

11. S.E. Kondratenko, Gas industry, 1, 46 (2017)

12. S.E. Kondratenko, Gas industry, 4, 76 (2017)

13. Z. Chen, J. He, H. Chen, L. Geng, P. Zhang, Energy, 224 (2021)

14. S. Faizollahzadeh Ardabili, B. Najafi, M. Aghbashlo, Z. Khounani, M. Tabatabaei, Fuel, 294 (2021)

15. F. Haghighat Shoar, B. Najafi, A. Mosavi, Energy Reports, 7, 1172 (2021)

16. W. Kamei, N. Sahoo, V. V. D. N. Prasad, Journal of Energy Resources Technology, Transactions of the ASME, 143(11) (2021)

17. D. Kashyap, S. Das, P. Kalita, Science of the Total Environment, 773 (2021)

18. Z. Liu, L.Yang, E. Song, J. Wang, A. Zare, T. A. Bodisco, R. J. Brown, Fuel, 293 (2021)

19. B.A. Oni, S.E. Sanni, A.J. Ibegbu, A.A. Aduojo, Energy Reports, 7, 607 (2021)

20. T. Ouyang, Z. Su, R. Yang, Z. Wang, X. Mo, H. Huang, Energy, 224 (2021)

21. C. Park, S. Oh, C. Kim, Y.Choi, Energy Reports, 7, 942 (2021)

22. Z. Wang, X. Fu, D. Wang, Y. Xu, G. Du, Fuel, 294 (2021) 